\title{
Socioeconomic and nutritional aspects of pregnant women assisted by Programa Bolsa Família: cohort NISAMI
}

\author{
Aspectos socioeconômicos e nutricionais de gestantes \\ do Programa Bolsa Família: coorte NISAMI
}

Cinthia Soares Lisboa (https://orcid.org/0000-0001-7421-0746) ${ }^{1}$

Jerusa da Mota Santana (https://orcid.org/0000-0002-8920-0097) ${ }^{2}$

Maria Lúcia Silva Servo (https://orcid.org/0000-0003-4809-3819) ${ }^{3}$

Ana Verônica Rodrigues Silva (https://orcid.org/0000-0002-3744-3652) ${ }^{2}$

Djanilson Barbosa dos Santos (https://orcid.org/0000-0002-6128-1155) ${ }^{2}$
${ }^{1}$ Programa de Pós-

Graduação em Saúde Coletiva, Universidade

Estadual de Feira de Santana (UEFS). Av. Transnordestina s/n, Novo Horizonte. 44036-900 Feira de Santana BA Brasil. cinthiaslisboa@gmail.com ${ }^{2}$ Centro de Ciências da Saúde, Universidade Federal do Recôncavo Baiano. Santo Antônio de Jesus BA Brasil. ${ }^{3}$ Departamento de Enfermagem, UEFS. Feira de Santana BA Brasil.

\begin{abstract}
The objective of this study was to evaluate the socioeconomic and nutritional assistance factors of pregnant women who are beneficiaries of the Bolsa Familia Program and were attended at a prenatal service in the city of Recôncavo da Bahia. A cohort study was conducted with 250 pregnant women from the prenatal service in 16 Family Health Units from August 2013 to December 2014. A structured and previously tested questionnaire was used to collect data. Socioeconomic and nutritional variables were used. It was identified that the average age was 28.3 years, of these, $85.2 \%$ studied until high school, $72.4 \%$ of pregnant women reported having income less than or equal to two minimum wages, with a mean of $1,036.3$ and $26.8 \%$ reported receiving the benefit. It was observed that $40 \%$ had a pre-gestational Body Mass Index of overweight, 38\% presented adequate weight gain for Gestational Age; $90.57 \%$ performed more than 7 consultations and $75.6 \%$ reported that they made use of alcoholic beverages or stopped in the gestation. The Bolsa Familia Program as an integrated strategy for social inclusion and economic development seems to have a protective effect on the nutritional health of pregnant women in the municipality.
\end{abstract}

Key words Gestation, Social policy, Nutritional status, Prenatal care
Resumo Objetivou-se avaliar os fatores socioeconômicos e de assistência nutricional de gestantes beneficiárias do Programa Bolsa Família que foram atendidas em serviço de pré-natal em município do Recôncavo da Bahia. Estudo transversal realizado com 250 gestantes do serviço de prénatal em 16 Unidades de Saúde da Família, de agosto de 2013 a dezembro de 2014. Para a coleta de dados, utilizou-se questionário fechado envolvendo informações socioeconômicas, antropométricas e de saúde da gestante. Identificou-se que a média de idade das gestantes foi de 28,3 anos, das quais $85,2 \%$ estudaram até o ensino médio, $72,4 \%$ das gestantes afirmaram possuir renda menor ou igual a dois salários mínimos, com uma média de 1.036,3 reais, e 26,8\% declararam receber o beneficio. Observou-se que $40 \%$ encontravam-se com Índice de Massa Corporal pré-gestacional de excesso de peso, 38\% apresentaram um ganho de peso adequado para Idade Gestacional; 90,57\% realizaram mais de 7 consultas, e 75,6\% relataram que fizeram uso de bebida alcoólica ou pararam na gestação. O Programa Bolsa Família, enquanto uma estratégia integrada de inclusão social e de desenvolvimento econômico, parece exercer efeito protetor na saúde nutricional das gestantes do município.

Palavras-chave Gestação, Política social, Estado nutricional, Assistência pré-natal 


\section{Introduction}

The gestation is a highly vulnerable life cycle due to being associated with higher nutritional and metabolic needs. In this period, many physical, physiological, and psychological changes that control maternal organic functions occur in the organism to ensure the development of the fetus ${ }^{1}$.

The inadequacy of maternal nutritional status in the gestational and pregestational period constitutes a public health issue, as it leads to the occurrence of gestational complications that negatively impact the course of the gestation. Both insufficient and excessive maternal weights are associated with gestational complications and adverse outcomes for both mothers and children. Among them is low weight at birth, macrosomia, prematurity, surgical birth, maternal diabetes, and maternal hypertension ${ }^{2}$.

The weight gain of the pregnant woman, being adequate to the pre-gestational weight and the gestational week, positively influences the birth weight of newborns, because, according to the International Statistical Classification of Diseases and Related Health Problems - $10^{\text {th }}$ Review (ICD-10), children born alive weighing 2.500 grams or less are considered to have an unsatisfactory development ${ }^{3}$.

In this context, the nutritional assistance during the gestation is essential for monitoring maternal nutritional status, as well as specific dietetic orientations for clinical, social, and economic conditions of every pregnant woman assisted in the prenatal services ${ }^{4}$.

The socioeconomic factors are considered social determiners of health. Among them are education level, sociodemographic status, skin color, occupation, physical exercise level, caloric diet, parity, smoking, alcohol consumption, and prenatal care ${ }^{5}$.

In the spectrum of economic aspects as a determining factor in nutritional status, the Brazilian social welfare program named Programa Bolsa Família (PBF) is relevant as a program of conditioning income transfer, aiming to fight poverty and hunger and to promote food and nutritional security ${ }^{6,7}$. In order to be continuously supported by this program, the beneficiary families need to fulfill the conditions related to education and health care, especially the latter, which is demanded continuous prenatal monitoring and attendance to diet and nutritional education activities.

This study is relevant for public health, especially for the mother-children group, once it aims to contribute to the discussion in this field, approaching nutritional and social determiners of health care that directly influence the nutritional status of pregnant women, taking into consideration the socioeconomic and nutritional factors of pregnant women from Recôncavo Baiano.

This research has shed light on peculiarities related to pregnancy in a region of Recôncavo Baiano, leading to outcomes that contribute to local managers responsible for health and social policies, in a context which this issue has drawn the attention of Institutions and researchers, especially those in the social epidemiology area, as well as public authorities.

Thus, this study aims to evaluate the socioeconomic and nutritional assistance factors of pregnant women who are beneficiaries of the PBF who are attended in prenatal care in the municipality of Recôncavo Baiano.

\section{Method}

This is a cross-sectional research aligned to a dynamic prospective cohort study with pregnant women selected from the NISAMI cohort baseline - genetic and nutritional risk factors during gestation associated with low weight at birth/prematurity, enrolled in family health care units named Unidades de Saúde da Família (USF) from Santo Antônio de Jesus, Bahia.

The municipality has 21 USFs, from which 16 are in the urban area, included in the study. The other 5 USFs were considered ineligible to compose a sample for being located in neighborhoods of difficult access - or situated in the rural zone - due to the insufficiency of human and economic resources.

The data of this research were collected through interviews with clinically healthy adult pregnant women, residing and domiciled in the urban area, and enrolled in the prenatal service at a USF, from August 2013 to December 2014. Women with twin pregnancy, teenagers, and others with Human Immunodeficiency Virus (HIV) were considered ineligible to compose a sample.

Thus, this research had the collaboration of 250 pregnant women. This sample was calculated based on the overweight prevalence of $48.1 \%$ among pregnant women residing in the city where the study was conducted ${ }^{9}$, with a sampling error of $3 \%$ and a power of $90 \%{ }^{10}$.

During prenatal services, pregnant women have been invited to participate in the research. Those who accepted signed a term of consent 
and answered a semi-structured questionnaire, covering topics such as socioeconomic, demographic, health and obstetric information, and access to social welfare programs. At that moment, the pregnant women had their weight and height assessed on the baseline. In a second stage, at the end of the third trimester of pregnancy, the data collection team returned to the prenatal service units to gather information from the patient's medical records about weight along the period of gestation and variables such as the number of prenatal consultations.

A Filizola ${ }^{\circledR}$ model 31 mechanical scale with a capacity of $150 \mathrm{Kg}$ and a $100 \mathrm{~g}$ precision has been used to measure the maternal weight, and, for height measurement, a Sanny ${ }^{\circledR}$ stadiometer, having a capacity of $200 \mathrm{~cm}$ and a $0.1 \mathrm{~cm}$ precision, then recording both measures with its respective replicate. The data from the baseline have been collected by undergraduate students - about to graduate in Nursing and Nutrition - previously trained by the project, and the data of the second stage, by professionals from trained family health teams. The research questionnaire undergone through two review steps after their completion, the former by the researchers themselves, and the latter, by the supervisors.

The gestational Body Mass Index (BMI) has been used as a proxy of the anthropometric status of pregnant women, classified according to the Atalah curve. The difference of weight between the last trimester of gestation and the pregestational phase has been defined as a parameter for weight gain and classified based on the recommendations of IOM $(2009)^{11}$.

The number of prenatal consultations, the Ministry of Health recommends that at least 06 prenatal follow-up consultations be carried out, preferably one in the first trimester, two in the second and three in the second and third trimester of pregnancy ${ }^{12}$.

In order to classify the pre-gestational nutritional status, the IOM-2009 applies the BMI obtained through the collected weight and height in the $1^{\circ}$ trimester of gestation, and then classifies the pregnant women in low weight $(\mathrm{BMI}<18,5$ $\left.\mathrm{kg} / \mathrm{m}^{2}\right)$, appropriate weight $(18,5 \leq \mathrm{BMI} \leq 24,9 \mathrm{~kg} /$ $\left.\mathrm{m}^{2}\right)$, overweight $\left(25,0 \leq \mathrm{BMI} \leq 29,9 \mathrm{~kg} / \mathrm{m}^{2}\right)$ and obesity $\left(\mathrm{BMI} \geq 30 \mathrm{~kg} / \mathrm{m}^{2}\right)$. Therefore, the method recommends adequate weight gain of 12,5 $\mathrm{kg}$ to $18 \mathrm{~kg}$ for pregnant women classified as low weight; $11,5 \mathrm{~kg}$ to $16,0 \mathrm{~kg}$ for those classified as appropriate weight; 7,0 to $11,5 \mathrm{~kg}$ for overweight group; and 5,0 to 9,0 kg for obesity group.

In this study, the weight gain during gestation is an outcome variable categorized by [(0) Ade- quate - low weight and adequate weight - and (1) Excessive Weight Gain]. The pregestational BMI is categorized by [(0) Adequate and (1) Excessive Weight Gain].

The enrollment in PBF and access to the benefits is the exposure variable of this study, categorized by [(0) Yes; (1) No]. Additionally, as covariates: maternal age [ 19 to $34 ;<19$ and $>34$ ], family income [ $>2$ Minimum Salaries; $\leq 2$ Minimum Salaries], education level $[<$ High School; $\geq$ High School Diploma], alcohol consumption [Not Consuming; Consuming but Quitting during Gestation], number of prenatal consultations [ $\geq 7$ Consultations; $<7$ Consultations], class [class B and C; class A], parity [ $\geq 2 ; \leq 2$ ]; skin color [not black; black], occupational status [active; not active] and gestational trimester [first, second, third].

The Epi Info 6.04 b program has been used for data digitalization, and the Data Analysis and Statistical Software (STATA ${ }^{\mathrm{TM}}$ ) version 12 has been applied for statistical analysis. Firstly, a descriptive study has been conducted, in which proportions have been used for categorical variables and rate, and standard deviation for continuous variables.

Bivariate analysis has been undertaken among independent variables (pre-gestational BMI, gestational weight gain, family income, education level, maternal age, prenatal consultations and alcohol consumption) and the outcome variable (Bolsa Família Program), measuring the gross prevalence ratio $(\mathrm{PR})$, along with its respective confidence index (CI) of 95\%. In statistical modeling, the variables present values of $p<0,200$. In the bivariate analysis, the Regression of the Poisson model has been introduced with considerable variation. Variables that present values of $p<0,05$ have been kept in the model after adjustments using covariables. PR and CI95\% estimations have been eventually obtained.

For identification of measurement and confounding factors, a stratified analysis has been conducted with estimations for each covariable, having CI95\%. The covariables that present outcomes $\mathrm{p} \leq 0,05$ in the intuitive model have been considered effect modifiers and through BreslowDay Test, comparing the saturated model to the reduced model. The variables that present relative differences between the adjusted measures of each covariable and the gross association measures higher or equal to $20 \%$ have been considered confounding variables.

This research was approved by the Ethics Commission of Faculdade Adventista de Fisioterapia da Bahia (under the CAAE identifier code: 4369.0.000.070-10) in 2011. 


\section{Results}

Table 1 shows the sociodemographic, nutritional and gestational characteristics of the population concerning this study. The characterization of the 250 pregnant women indicates that the average age is $28.3(\mathrm{SD}=5.6)$, whom $84 \%$ studied until high school, having 9.9 average years of study $(\mathrm{SD}=2.8) ; 70.8 \%$ of pregnant women said their family income is lower than or equal to two minimum salaries, having an average income of 1036.3 reals $(S D=586.3)$, and $28.8 \%$ of them claimed to be beneficiary of governmental support, specifically the PBF.

Regarding the anthropometric profiles of the pregnant women, $40 \%$ had pregestational overweight, having an average of $25.8 \mathrm{Kg}(\mathrm{SD}=5.7)$, and $64.8 \%$ had adequate weight gain concerning gestational age, having an average of $12.9 \mathrm{Kg}$ $(\mathrm{SD}=4.9$, Table 2$), 85.6 \%$ had less than one child, $84 \%$ were black, $54.8 \%$ were not active in terms of occupational status and more than half (54\%) were in the second trimester of pregnancy.

When considering the number of prenatal consultations, $68.8 \%$ reported more than seven. Also, 75.6\% said that they have consumed alcohol or quit during pregnancy.

In the multivariate analysis adjusted by covariates (pregestational BMI, gestational weight gain, income, education level, maternal age, prenatal consultations, and alcohol consumption) for the association between sociodemographic and nutritional characteristics according to the PBF's policies, these variables performed as protector factors. The observed prevalence of appropriate pregestational IBM is $19 \%(\mathrm{PR}=0,19$ CI95\%: 0,37-0,18) lower in pregnant women who are beneficiaries of PBF when compared to those who are not. The beneficiaries present higher income ( $\mathrm{PR}=0,69$ CI95\%: 0,58-0,83), undergo more prenatal consultations $(\mathrm{PR}=0,82 \mathrm{CI} 95 \%$ : 0,68-1,0) and quit alcohol consumption during gestation ( $\mathrm{PR}=0,76 \mathrm{CI} 95 \%$ : 0,63-0,91) (Table 3).

\section{Discussion}

This study suggested that the PBF, as an integrated approach of social inclusion and economic development, implies protector effects for the nutritional health of pregnant women. Therefore, the results show that the beneficiary women have better nutrition and health conditions during gestation according to the variables considered in this study.
It is relevant to enhance that the major PBF holders are women, who take the responsibility and choice over the application of the resources to fight hunger and poverty ${ }^{12,13}$. Villatoro ${ }^{14}$, based on the World Bank studies, claims that when the benefits are transferred to women, they take more responsibility and capacity of negotiation, and assume the leading role in their families.

The PBF is not only about a direct transference of income to families, aiming to mitigate poverty in the short term, but it is also about the conditionalities that contribute to the access of the beneficiary women to health and education services, hence contributing to improvements in health status, such as the increasing use of prevention services, the improvement of immunization coverage, and encouraging healthy behaviors ${ }^{7,8}$.

In this study, it has been observed that more than half of pregnant women fall into the age group of 19-34, which is an adequate age group for female reproduction since, in this stage, there is a minor risk for obstetric complications ${ }^{15}$.

When considering the education level, the study shows that most of them accomplished high school diploma. It is known that low education level is related to infant mortality, growth deficit, and sub nutrition. Additionally, pregnant women have also a minor chance of accomplishing more than six prenatal consultations and more difficulties in following the vaccination calendar ${ }^{16}$. Thus, the educational profile of the studied pregnant women can provide a significant prognostic concerning the risks previously mentioned.

Among the conditionalities of this program, the ones directed to the studied cycle stand out, which ensure the access of pregnant women to prenatal and postpartum consultations and to the participation of actions of food and nutrition education in the primary health care network, especially in PSF $^{12}$. However, $15.38 \%$ of beneficiaries had less than six consultations during prenatal care.

According to Rasia and Albernaz ${ }^{17}$, despite the progress related to the spread of prenatal services in Brazil, it is possible to identify inequalities in prenatal care services offered to pregnant women. Adverse socioeconomic conditions and lower school levels are the factors associated to worse nutritional and health conditions - the range of pregnant women that less search for prenatal assistance, emphasizing how social inequality restrains access and leads to poor health care services, such as prenatal one, and enhancing what claims the inverse care $\operatorname{law}^{18,19}$. 
Table 1. Sociodemographic, nutritional and gestational characteristics of pregnant women assisted in the Family Health Units from Santo Antônio de Jesus district, Bahia, 2011.

\begin{tabular}{|c|c|c|c|c|c|c|}
\hline \multirow{3}{*}{ Variables } & \multirow{3}{*}{$\%$} & \multicolumn{4}{|c|}{ Programa Bolsa Família } & \multirow{3}{*}{$\begin{array}{c}\text { P- } \\
\text { value }^{\star}\end{array}$} \\
\hline & & \multicolumn{2}{|c|}{ No } & \multicolumn{2}{|c|}{ Yes } & \\
\hline & & $\mathbf{N}$ & $\%$ & $\mathbf{N}$ & $\%$ & \\
\hline Maternal Age (years) & & & & & & 0,329 \\
\hline 19 to 34 & 76 & 142 & 77,6 & 48 & 71,64 & \\
\hline$<19$ and $>35$ & 24 & 41 & 22,4 & 19 & 28,36 & \\
\hline Family Income & & & & & & 0,000 \\
\hline$\leq 2 \mathrm{MS}$ & 72,4 & 119 & 65,03 & 62 & 92,54 & \\
\hline$>2 \mathrm{MS}$ & 27,6 & 64 & 34,97 & 5 & 7,46 & \\
\hline Education Level & & & & & & 0,402 \\
\hline$\geq$ High School Diploma & 85,2 & 158 & 86,34 & 55 & 82,09 & \\
\hline$<$ High School & 14,8 & 25 & 13,66 & 12 & 17,91 & \\
\hline Alcohol Consumption & & & & & & 0,148 \\
\hline Not Consuming & 24,4 & 49 & 26,78 & 12 & 17,91 & \\
\hline Consuming but Quitting during Gestation & 75,6 & 134 & 73,22 & 55 & 82,09 & \\
\hline Weight Gain & & & & & & 0,830 \\
\hline Adequate & 38 & 68 & 37,16 & 27 & 40,3 & \\
\hline Excessive Weight Gain & 30,8 & 56 & 30,6 & 21 & 31,34 & \\
\hline Low Weight & 31,2 & 59 & 32,24 & 19 & 28,36 & \\
\hline Pregestational BMI & & & & & & 0,222 \\
\hline Adequate & 48,8 & 95 & 51,91 & 27 & 40,3 & \\
\hline Excessive Pregestational Weight Gain & 40 & 70 & 38,25 & 30 & 44,78 & \\
\hline Low Weight & 11,2 & 18 & 9,84 & 10 & 14,93 & \\
\hline Number of Consultations & & & & & & 0,830 \\
\hline$\geq 7$ & 90,57 & 37 & 92,5 & 11 & 84,62 & \\
\hline$<7$ & 9,43 & 3 & 7,5 & 2 & 15,38 & \\
\hline Class & & & & & & 0,797 \\
\hline Class B and C & 98,8 & 181 & 98,91 & 66 & 98,51 & \\
\hline Class A & 1,2 & 2 & 1,09 & 1 & 1,49 & \\
\hline Parity & & & & & & 0,582 \\
\hline$\geq 2$ & 14,4 & 25 & 13,66 & 11 & 16,42 & \\
\hline$\leq 1$ & 85,6 & 158 & 86,34 & 56 & 83,58 & \\
\hline Skin color & & & & & & 0,237 \\
\hline Not Black & 16 & 32 & 8,13 & 15 & 7,14 & \\
\hline Black & 84 & 106 & 91,87 & 97 & 92,85 & \\
\hline Occupational Status & & & & & & 0,000 \\
\hline Active & 45,2 & 100 & 58,4 & 26 & 32,11 & \\
\hline Not active & 54,8 & 80 & 41,6 & 44 & 67,88 & \\
\hline Gestational Trimester & & & & & & 0,069 \\
\hline First & 34,4 & 70 & 38,25 & 16 & 23,88 & \\
\hline Second & 54 & 91 & 49,73 & 44 & 65,67 & \\
\hline Third & 11,6 & 22 & 12,02 & 7 & 10,45 & \\
\hline
\end{tabular}

${ }^{*}$ Test chi-square. MS - Minimum Salary; BMI - Body Mass Index.

Source: Authors.

Regarding the monthly family income, most of the pregnant women reported having some equal to or lower than two minimum salaries, characterizing a low-income population. However, the PBF allowed the amplification of the beneficiary income, revealing itself as a signifi- cant factor to expand the access to food for the entire family, and, therefore, an improvement in the nutritional health.

Other results related to the same population demonstrate that beneficiary women include, in their daily diet, the fundamental and healthy 
Table 2. Sociodemographic and nutritional characteristics of pregnant women as beneficiaries and nonbeneficiaries of Programa Bolsa Família (PBF) from Santo Antônio de Jesus district, Bahia, 2011.

\begin{tabular}{lrrrr}
\hline & \multicolumn{3}{c}{ PBF Beneficiary } \\
\cline { 2 - 5 } \multicolumn{1}{c}{ Characteristics } & \multicolumn{3}{c}{ Yes } & No \\
\cline { 2 - 5 } & Average & 5,6 & Average & SD \\
\hline Maternal Age & 28,3 & 2,8 & 10,8 & 6,0 \\
Years of Education & 9,9 & 586,3 & 1672,6 & 1269,4 \\
Family Income & 1036,3 & 5,7 & 23,8 & 4,2 \\
Pregestational BMI & 25,8 & 4,9 & 12,8 & 4,9 \\
Gestational Weight Gain & 12,9 & 2,1 & 7,3 & 2,0 \\
Prenatal Consultations & 6,7 & & & \\
\hline
\end{tabular}

Source: Authors.

Table 3. Crude and adjusted analysis for the association between sociodemographic and nutritional characteristics and access to the PBF benefit of pregnant women assisted in the Family Health Units from Santo Antônio de Jesus district, Bahia, 2011.

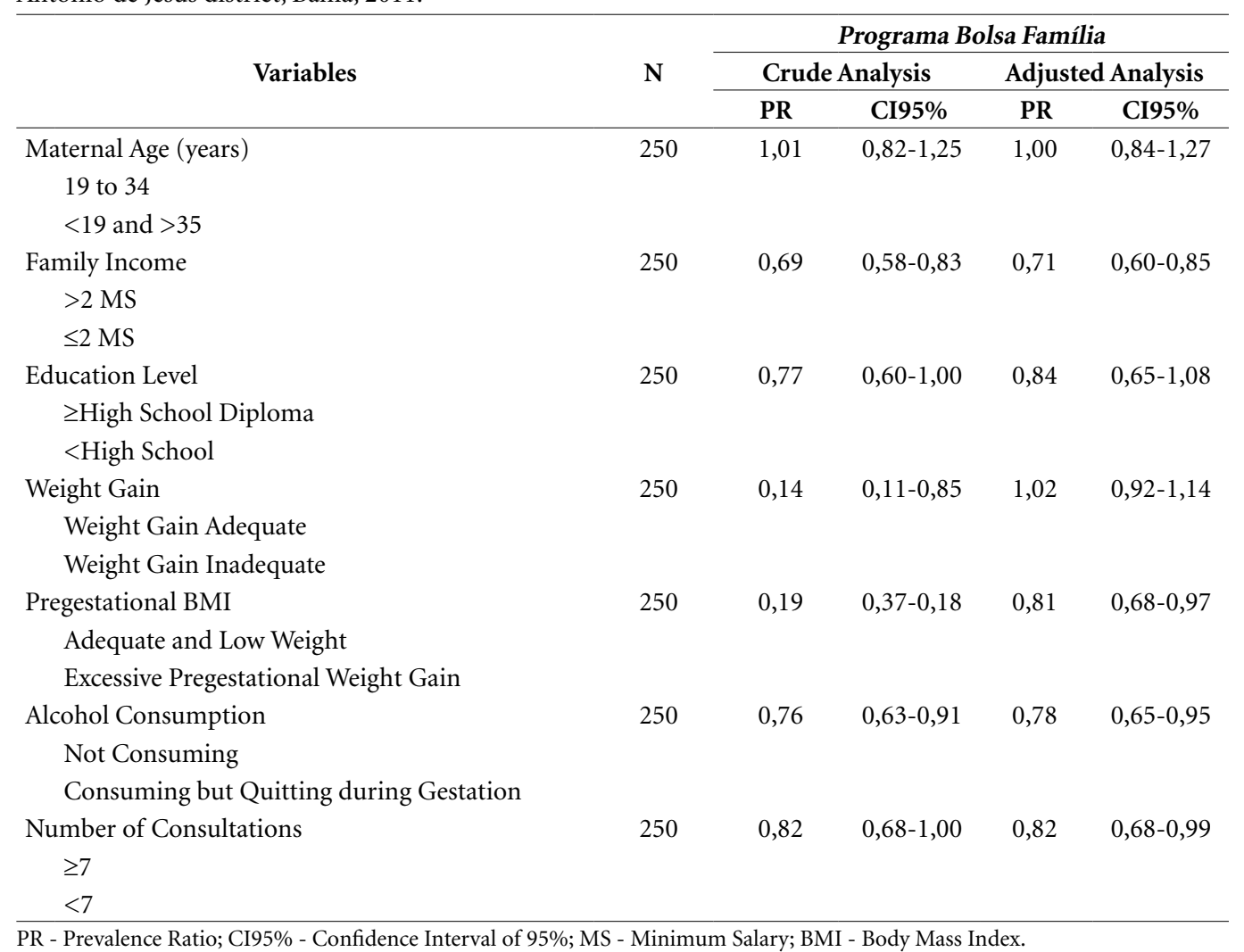

Source: Authors.

food group of the Brazilian population's diet (milk and its derivates, beans, meat, eggs, and cereals), although low consumption of fruit and vegetables has been also observed ${ }^{10}$.
These results are similar to those found in a study conducted in Porto Alegre ${ }^{17}$. It is important to stress that, in this present study, the family income of PBF beneficiary women is more than a 
minimum salary, and this program is associated with the increase in family income, which might indicate a significant factor to expand the access to food for the entire family, and, therefore, an improvement in the nutritional health.

In this study, a higher adequate weight gain prevalence has been observed, which converges with other studies ${ }^{20,21}$. Thus, the nutritional assistance during gestation must be performed to identify the maternal nutritional status, and to guide pregnant women's diet according to the result obtained in the assessment.

Some studies suggest that, when assisted with nutritional orientation, pregnant women enhance their nutritional status, both low weight and overweight groups of pregnant women. In other words, changes in diet, among other factors, are related to the awareness of adequate nutrition during pregnancy ${ }^{4,22}$.

Inadequacy of the maternal nutritional status in the pregestational and the gestational phases leads to gestational intercurrences that negatively affect the course of gestation ${ }^{23}$. Some of those intercurrences, such as variation in weight gain, are associated with higher maternal and perinatal mortality rates, higher risk of abortion, prematurity, and low birth weight ${ }^{24}$.

The study performed in Porto Alegre recorded a high percentage of obese women among beneficiaries of PBF, which contrasts the outcomes of the present study, as the studied pregnant women presented better control on weight gain $^{25,26}$. Alongside, in the research conducted in Recôncavo da Bahia with the same population, the study identified that the PBF directly and negatively affects the pregnant women's BMI during gestation, indicating that they had lower BMI during the gestational cycle ${ }^{10}$.

Recent studies have been demonstrating the positive impact of PBF in the maternal-infant health condition and the reduction of infant mortality ${ }^{27,28}$. The improvement of children's health conditions and nutritional status was expected as a positive impact of PBF, and the scientific evidence of this has been widely registered $^{10,12,29,30}$.

It is relevant to emphasize that, as conditionality of the program, both pregnant women and nursing mothers must participate in both prenatal and postnatal consultations and activities of nutritional education ${ }^{31}$. In general, the literature describes monitoring contributes to both mother and fetus ${ }^{31}$. Thus, the PBF plays the role of protector to the mentioned variable. In other words, the beneficiary related to this present investiga- tion accomplished more than seven consultations.

Therefore, on the basis of researches, it is debated that the PBF encourages families to search for preventive health care, in which the basic health services for the most vulnerable groups are strengthened as a consequence of the PBF conditionalities, with positive effects in the health of pregnant women and children ${ }^{12,32}$.

In this investigation, most of the pregnant women have either consumed alcohol or quit during gestation. These outcomes meet the results in the studies performed by both Freire et al..$^{33}$ in Rio de Janeiro and Havens et al. ${ }^{34}$, in the United States of America, in which the prevalence of alcohol consumption was $7.4 \%$ and $10 \%$, respectively.

It is known that alcohol consumption leads to complications also in maternal health, such as cardiovascular disease, cancer, depression, and neurologic disturb. Moreover, it is related to insufficient gestational weight gain, lower number of prenatal consultations, and increased risk of consumption of other drugs ${ }^{35}$.

In Brazil, prenatal services have broad and significant coverage, revealing an ideal moment for intervention and prevention of the use of substances harmful for mothers and children, since, in this period, there is an intensification in the connection between the health professionals and the pregnant women, ensuring, therefore, better opportunities of intervention to occur ${ }^{36}$.

The authors acknowledge that the publications on this investigated topic is scarce, hence it was a limitation for the development of this research. Thus, the present study advances in the methodologic delineation and approach of the primary data. However, new studies must be performed, more extensive and with different approaches, in order to clarify the impacts that this social policy has been generating.

Despite all methodological efforts applied to this study, some aspects inherent to the classification of variables may lead to limitations, illustrated by the lack of standardization of BMI cut points to the classification of pregestational anthropometric status, which might lead to differences in outcomes among studies. However, this study has followed the WHO standard $(1995)^{11}$, which has been the most applied standard, and researches from the scientific literature that uses the same cut point have been selected to make a comparison of results.

Based on the analyzed data, it is possible to find evidence about the positive implications 
that the PBF performs in this life cycle, suggesting as a protector factor to the mother-fetus binomial, among other benefits, to provide better nutritional attention, and to contribute to the actions of health promotion and prevention from the risk factors.

Thus, they can contribute with subsidies to the social policies directed to the improvement of nutritional, health, and living conditions of mothers and children of the most vulnerable population in the country.

\section{Collaborations}

CS Lisboa contributed with the conception and delineation of the study, data interpretation, writing and critical revision of intellectual content. JM Santana and AVR Silva contributed with the analysis and writing of the manuscript. MLS Servo and DB Santos with the writing and revision of the manuscript. All authors read and approved the final manuscript. 


\section{References}

1. Accioly E, Saunders C, Lacerda EMA. Nutrição em obstetrícia e pediatria. $2^{\mathrm{a}}$ ed. Rio de Janeiro: Guanabara-Koogan; 2009.

2. Crane JM, White J, Murphy P, Burrage L, Hutchenes D. The effect of gestational weight gain by body mass index on maternal and neonatal outcomes. J Obstet Gynaecol Can 2009; 31(1):28-35.

3. Noronha GA, Torres TG, Kale PL. Análise da sobrevida infantil segundo características maternas, da gestação, do parto e do recém-nascido na coorte de nascimento de 2005 no município do Rio de Janeiro RJ, Brasil. Epidemiol Serv Saude 2012; 21(3):419-430.

4. Lisboa CS, Bittencourt LJ, Santana JM, Santos DB. Assistência nutricional no pré-natal de mulheres atendidas em unidades de saúde da família de um município do Recôncavo da Bahia: um estudo de coorte. Demetra 2017; 12(3):713-731.

5. Silva CFN, Souza MC, Valença Neto PF, Cassotti CA. Avaliação do estado nutricional das gestantes assistidas pela Estratégia de Saúde da Família. Rev Digi 2014; 18:190.

6. Martins APB, Canella DS, Baraldi LG, Monteiro CA. Transferência de renda no Brasil e desfechos nutricionais: revisão sistemática. Rev Saude Publica 2013; 47(6):1159-1171.

7. Brasil. Controladoria-Geral da União. Programa Bolsa Família: orientações para acompanhamento das ações do Programa Bolsa Família. Brasília: Secretaria de Prevenção da Corrupção e Informações Estratégicas; 2012.

8. Moraes VD, Pitthan RGV, Machado CV. Programas de Transferência de Renda com Condicionalidades: Brasil e México em perspectiva comparada. Saude Debate 2018; 42(117):364-381.

9. Santana JM, Queiroz VAO, Brito SM, Santos DB, Assis AMO. Patrones en el embarazo Consumo de alimentos: Un estudio longitudinal. Nutr Hosp 2015; 32(1):130-138.

10. Santana JM. Segurança Alimentar e Nutricional: Influência do programa bolsa família nos padrões de consumo alimentar e antropométricos de gestantes usuárias da atenção básica à saúde [tese]. Salvador: Instituto de Saúde Coletiva da UFBA; 2017.

11. Atalah E, Castillo CL, Castro RS, Amparo AP. Propuesta de un Nuevo estándar de evaluación nutritional de embarazadas. Rev Med Chile 1997; 125(12):14291436.

12. Brasil. Ministério da Saúde (MS). Secretaria de Atenção à Saúde. Departamento de Ações Programáticas Estratégicas. Área Técnica de Saúde da Mulher. Prénatal e Puerpério: atenção qualificada e humanizada. Brasília: MS; 2006.

13. Assis AMO, Costa PRF, Silva MCM, Santana MLP, Pitangueira JCD, Fonseca NSS, Pinheiro SMC, Santos SMC. Effectiveness of the Brazilian Conditional Cash Transfer Program - Bolsa Alimentação - on the variation of linear and ponderal increment in children from northeast of Brazil. Nutr Hosp 2015; 31(6):27862794.

14. Villatoro P. Programas de transferências monetárias condicionadas: experiências na América Latina. Rev CEPAL 2010; (n. esp.):127-141.
15. Zimmermann CR, Espínola GM. Programas Sociais no Brasil: um estudo sobre o Programa Bolsa Família no interior do Nordeste brasileiro. Cad CRH 2015; 28(73):147-164.

16. Sass A, Gravena AAF, Pelloso SM, Marcon SS. Resultados perinatais nos extremos da vida reprodutiva e fatores associados ao baixo peso ao nascer. Rev Gaucha Enferm 2011; 32(2):352-358.

17. Rasia ICRB, Albernaz E. Atenção pré-natal na cidade de Pelotas, Rio Grande do Sul, Brasil. Rev Bras Saude Mater Infant 2008; 8:401-410.

18. Salvador BC, Paula HAA, Souza CC, Cota AM, Batista MA, Pires CR, Martins PC, Cotta RMM. Atenção prénatal em Viçosa-MG: Contribuições para discussão de políticas públicas de saúde. Rev Med Minas Gerais 2008; 18(3):167-174.

19. Gonzaga ICA, Santos SLD, Silva ARV, Campelo V. Atenção pré-natal e fatores de risco associados à prematuridade e baixo peso ao nascer em capital do nordeste brasileiro. Cien Saude Colet 2016; 21(6):19651974.

20. Demétrio F, Pinto EJ, Assis AMO. Fatores associados à interrupção precoce do aleitamento materno: um estudo de coorte de nascimento em dois municípios do Recôncavo da Bahia, Brasil. Cad Saude Publica 2012; 28:641-650.

21. Vítolo MR, Bueno MSF, Gama CM. Impacto de um programa de orientação dietética sobre a velocidade de ganho de peso de gestantes atendidas em unidades de saúde. Rev Bras Ginecol Obstet 2011; 33(1):13-19.

22. Oliveira ACM, Pereira LA, Ferreira RC, Clemente APG. Estado nutricional materno e sua associação com o peso ao nascer em gestações de alto risco. Cien Saude Colet 2018; 23(7):2373-2382.

23. Francisqueti FV, Rugolo LMSS, Silva EG, Peraçolli JC, Hirakawa HS. Estado nutricional materno na gravidez e sua influência no crescimento fetal. Rev SimbioLogias 2012; 5(7):74-86.

24. Belarmino GO, Moura ERF, Oliveira NC, Freitas GL. Risco nutricional entre gestantes adolescentes. Acta Paul Enferm 2009; 22(2):169-175.

25. Borba GG, Neves ET, Arrué AM, Silveira A, Zamberlan KC. Fatores associados à morbimortalidade neonatal: um estudo de revisão. Rev Saude (Santa Maria) 2014; 40(1):9-16.

26. Santos MMAS, Baião $\mathrm{MR}$, Barros $\mathrm{DC}$, Pinto $\mathrm{AA}$, Pedrosa PLM, Saunders C. Estado nutricional prégestacional, ganho de peso materno, condições da assistência pré-natal e desfechos perinatais adversos entre puérperas adolescentes. Rev Bras Epidemiol 2012; 15(1):143-154.

27. Coelho NLP, Cunha DB, Esteves APP, Lacerda EMA, Theme Filha MM. Padrão de consumo alimentar gestacional e peso ao nascer. Rev Saude Publica 2015; 49:62.

28. Rosa JAO. Estado Nutricional e consumo de alimentos de beneficiários do Programa Bolsa Família em uma unidade básica de saúde de Porto Alegre-RS [tese]. Rio Grande do Sul: Universidade Federal do Rio Grande do Sul; 2011. 
29. Rasella D, Aquino R, Santos CAT, Paes-Sousa R, Barreto ML. Effect of a conditional cash transfer programme on childhood mortality: a nationwide analysis of Brazilian Municipalities. Lancet 2013; 382(9886):5764.

30. Shei A. Brazil's conditional cash transfer program associated with declines in infant mortality rates. Health Affairs 2013; 32(7):1274-1281.

31. Segura-Pérez S, Grajeda R, Pérez-Escamilla R. Conditional cash transfer programs and the health and nutrition of Latin American children. Rev Panam Salud Publica 2016; 40(2):124-137.

32. Ford KJ, Lourenço BH, Cobayashi F, Cardoso MA. Health outcomes of the Bolsa Família program among Brazilian Amazonian children. Rev Saude Publica 2020; 54:2.

33. Freire K, Padilha PC, Saunders C. Fatores associados ao uso de álcool e cigarro na gestação. Rev Bras Ginecol Obstet 2009; 31(7):335-341.

34. Havens JR, Simmons LA, Shannon LM, Hansen WF. Factors 27. associated with substance use during pregnancy: results from a national sample. Drug Alcohol Depend 2009; 99(1-3):89-95.

35. Magalhães Júnior HM, Jaime PC, Lima AMC. O papel do setor saúde no programa bolsa família: histórico, resultados e desafios para o sistema único de saúde. In: Campello T, Neri MC, organizadores. Programa Bolsa Família: uma década de inclusão e cidadania. Brasília: Ipea; 2014. p. 91-107.

36. Campello T. Uma década derrubando mitos e superando expectativas. In: Campello T, Neri MC, organizadores. Programa Bolsa Família: uma década de inclusão e cidadania. Brasília: Ipea; 2013. p. 15-24.

Article submitted 25/02/2020

Approved 21/11/2020

Final version submitted 23/11/2020

Chief editors: Romeu Gomes, Antônio Augusto Moura da Silva 